\title{
From Farming to Fishing: Marine Resource Conservation and a New Generation of Fishermen
}

\author{
Nicole Versleijen ${ }^{1}$ and Jan Hoorweg ${ }^{2}$ \\ ${ }^{1}$ P.O. Box 3857, Zanzibar, Tanzania; ${ }^{2}$ African Studies Centre, P.O. Box 9555, 2300 RB Leiden, the Netherlands
}

\begin{abstract}
Keywords: Artisanal fishers, household survey, income diversification, marine conservation, Kenya
\end{abstract}

\begin{abstract}
This paper examines the arrival of a new group of fishermen on the Kenyan coast and what this has meant for the state of fishery resources. It reviews four subject areas: access and the number of fishermen; the fishermen's identity; the choice of fishing gear; and the fishing grounds selected. Data were collected from a small number of fishing households in the villages of Uyombo and Takaungu in Kilifi District, using mainly qualitative research methods. Local households on the Kenyan coast face increasing pressure on land as well as on marine resources. The declining economic situation and greater pressure on land have made people turn to fishing as an income-generating activity. This group of fishermen is referred to as the 'new' generation of fishermen as they have been involved in fishing for only one or two generations (including the current one) in contrast to the 'old' generation from families who have been fishing or in fishingrelated activities for much longer. The old generation of fishermen and their households have also diversified their incomes, with many fishing households turning to farming, for example, with women and grown-up children involved in various activities. The new generation of fishermen, mainly of the Mijikenda population group, has often been blamed for the loss of traditional access regulations and for using harmful fishing gear. This paper discusses the new generation of fishermen and their identity as they perceive it and relates this to employment generation as a policy measure for marine conservation.
\end{abstract}

\section{INTRODUCTION}

Kenya has about $600 \mathrm{~km}$ of coastline where artisanal fishing is an important economic activity. However, fishery resources have been coming under increasing pressure. Many of the areas close to shore are heavily utilized with catches above the Maximum Sustainable Yield (McClanahan, 1996). Some areas further offshore have the potential for higher yields (McClanahan and Obura, 1996) but this requires investment in vessels and equipment that is beyond the means of most fishermen. Major increases in fish catches are unlikely in the near future. Artisanal fishermen are contributing to the degradation of marine resources because intensive fishing in certain areas can affect the ecological balance and result in a loss of fish stock. Destructive fishing practices, such as the use of seine nets and poison, can alter the environment as well as the ecological balance of the reef and the seabed. Fishermen are aware that their growing numbers are increasing the pressure on marine resources but they are at a loss as to how to deal with the situation (Versleijen, 2001).

Many coastal inhabitants depend on marine resources for their livelihoods, with coral reefs playing a particularly important role. In addition to providing construction materials, ornamental objects and medicinal products, coral reefs harbour many fish species. Coral reefs provide feeding, 
spawning and breeding grounds, as well as shelter and refuge from predators for the young fish and form the backbone of artisanal fishing along this coast. Due to their proximity to shore, fishermen do not necessarily need boats to reach these fishing grounds. About $80 \%$ of the fish landed on the Kenya coast are from inshore fisheries (McClanahan and Obura, 1995). In all, there are an estimated 10,000-12,000 fishers with 2,500-3,000 of them based on the Kilifi/Malindi coast (Hoorweg et al., 2008a). Over the last decade, many of the reefs have started to show signs of degradation as a result of overexploitation and pollution (McClanahan and Obura, 1996; UNEP, 1998; Aloo, 2000; Obura, 2001).

Faced with reduced catches and more competition from fellow artisanal fishermen as well as foreign fishermen, tourism and human settlement, a possible livelihood alternative lies in income diversification. Many fishermen are already involved in other income-generating activities. Hoorweg et al. (2008a) report that two-thirds of the fishers in a household survey had diversified their income in some way. Cinner and McClanahan (2006) mention that households in Takaungu have a mean of 1.9 occupations per household.

Income diversification is a survival strategy in rural households across Africa (Ellis 2000) and is also a favoured strategy for reducing risk. Diversification is expected to improve a household's income, resulting in higher income and/or a better income spread. Not only fishermen have started to diversify their livelihoods, many coastal farmers are now also seeking to diversify their sources of income. Due to increased pressure on land, the same shambas (farming plots) have to support a larger number of people. An increasing number of households are turning to fishing and in one of the companion surveys, more than $80 \%$ of Mijikenda fishers were first-generation fishers with the father not being a fisherman (Hoorweg et al., 2008a).

The focus in this paper is on the access that the new generation have, their identity once they start fishing, the fishing gear they use and the fishing grounds they frequent. The central research question concerns the livelihood strategies and income diversification of the new generation of fishermen and what their entry in the sector implies for the state of fishery resources.

\section{APPROACH AND METHODS}

\section{Local Communities}

A distinction was made in the present study between the 'new' and 'old' generations of fishermen. The 'new' generation consists of fishermen with no background in fishing at all or members of only one earlier family generation involved in fishing. Fishermen from families that have been engaged in fishing or fishingrelated activities for more generations are referred to as the 'old' generation of fishermen

Research focused on two villages in Kilifi District on the Kenyan coast, one with easy access to income-generating activities, the other with limited employment opportunities: Takaungu and Uyombo respectively. Takaungu is situated between Kilifi and Mombasa, and Uyombo between Kilifi and Malindi (Figure 1). The two villages are very different, particularly regarding physical accessibility and diversity in the villagers' income-generating activities.

The differences between Takaungu and Uyombo are pronounced and self-evident. Takaungu is a small town of 1,500 people (Wikipedia 2008), whereas Uyombo is a village with fewer than 30 houses, and less than 200 residents. Uyombo can be reached on foot or by bicycle and although it is possible to reach the village by car, this involves finding a route through the shambas and mangrove swamps. From Takaungu, there is a road to the Malindi-Mombasa trunk road and a choice of transport. These range from matatus, which are small vans - usually Nissans - operated as a means of public transport on fixed routes, to private cars, small trucks, which supply the shops in Takaungu or carry blocks from the quarry in Timboni, and bicycle taxis. Mombasa and Kilifi can be reached within an hour. A small boat operates a ferry service across Takaungu Creek from where the staff quarters of the Kilifi Plantations can be reached. From Uyombo, however, it is necessary to walk to the trunk road and wait for a matatu to Malindi, Watamu or Kilifi. It is possible to cross Mida Creek by boat, depending on the tide, to reach Watamu, although there is no ferry service.

Most of the fishermen who fish at Takaungu live in or near the town. Many houses are nowadays constructed of blocks with roofs made of iron sheets. 


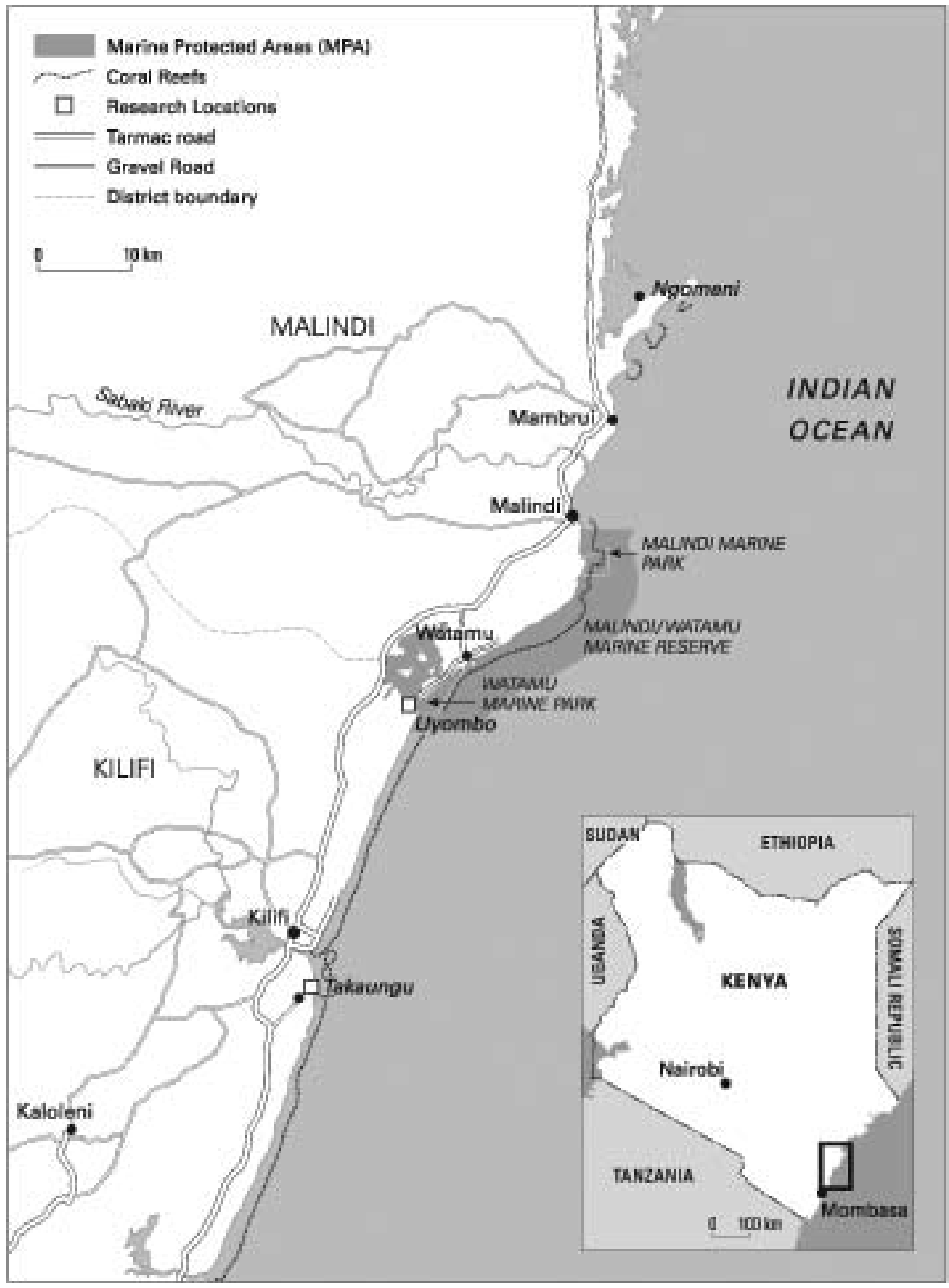

Fig. 1. Map of the Kenyan Coast with Study Locations 
Most people have access to running water in or near their house, while a few houses also have electricity. Several shops can be found offering diverse products, and vegetables are sold directly from people's homes. There are several eating places, a primary school, secondary school and Islamic schools. The subchief's office and a health dispensary are also situated there.

Takaungu was settled in the early 19th Century by members and clients of the Mazrui family. It is likely that migrating fishers from the Bajun Islands, to the north, had already set up a temporary fishing village there before the Mazrui arrived, as they are known to have done so at many places along the coast. Certainly other Bajun people followed in numbers to the growing settlement (Koffsky 1977) and later people belonging to the Mijikenda group also moved to the town. Takaungu has grown considerably in size and where once there were shambas, there are now houses and farming activities have moved to the outskirts of town.

Uyombo can be divided into two parts: the landing site, also known as Bandarini, and Uyombo proper which lies inland and is an agricultural area. The fishing activities are concentrated in Bandarini, although fishermen come from Bandarini as well as Uyombo proper, and even further away. Bandarini has a relatively short history with the first settlement dating from the 1930s when a Bajun fisherman from Lamu decided to build a house and move his family there. Most of the land in or near Bandarini is, or was, owned by this family. Other people settled in Bandarini but it has remained a small village. (In this paper, the name Uyombo is further used to include Bandarini.) Many of the fishermen living inland walk long distances to reach the landing site, while others have built temporary shelters where they spend the night when fishing, before returning to their homesteads. Many are farmers who have turned to fishing and whose homesteads and shambas are more than an hour's walk away. There is one shop and a few permanent houses which are owned by the shopkeeper (the fish trader) while the original house of the Bajun fisherman from Lamu is still used by his descendants.

As a result of its modest size and poor accessibility, income-generating activities in Uyombo are related to either fishing or agriculture, such as selling fish, palm-wine tapping and selling, cash-crop cultivation, farm labour and plaiting makuti (roofing materials from palm leaves). A more diverse scale of activities might have been expected considering the nearby Watamu Marine National Park. People from other villages and from upcountry have found employment in Watamu as wildlife rangers, hotel employees, safari sellers, beach vendors (of curios) and boat operators. In Takaungu there is a much wider range of incomegenerating possibilities, for example, stone-block cutting, construction, teaching and others. There are craftsmen and tailors resident in Takaungu but they are not found in Uyombo hence residents have to go to Matsangoni on the Malindi-Mombasa road when such services are needed.

Uyombo is situated next to the Watamu Marine National Park, which was first declared a marine reserve in 1962, followed by one in Malindi in 1964 (Government of Kenya, 1964) and later, both were officially designated as Marine Parks in 1968. In Kenya, a marine park is an area where marine resources are protected by not allowing fishing or other extractive activities of any form. Adjacent to the parks are the marine reserves where fishing by artisanal fishermen is allowed but restricted by the regulations stipulated in the Fisheries Act (Government of Kenya, 1991). The Kenya Wildlife Service (KWS) is responsible for the overall management of the protected area and day-to-day management is the responsibility of a warden who is assisted by park rangers (McClanahan et al., 2005). Takaungu has no parks nearby and the Mombasa Marine National Park is about $40 \mathrm{~km}$ away.

The population in the study areas consists mostly of Swahili, Bajun and Mijikenda people (Table 1). In Takaungu, the Swahili and Bajun tend to live in the town centre (the oldest part), and the Mijikenda mostly live on the outskirts. In Uyombo, the Bajun live at the landing site where some Mijikenda have also built permanent houses. The main population group is the Mijikenda, agriculturalists who used

Table 1. Ethnic origin of fishermen by landing site (\%)

\begin{tabular}{lcc}
\hline & $\begin{array}{c}\text { Uyombo } \\
\text { (N=13) }\end{array}$ & $\begin{array}{c}\text { Takaungu } \\
(\mathbf{N = 1 1 )}\end{array}$ \\
\hline Swahili & 0 & 18 \\
Bajun & 15 & 9 \\
Mijikenda & 77 & 73 \\
Other & 8 & 0 \\
\hline
\end{tabular}


to live in the coastal uplands where the main crops were sorghum, finger and pearl millet and cowpeas and where they also kept small livestock and a few cattle (Waaijenberg, 1993, 1994, 2000). Over the course of the last century, the Mijikenda spread out along the coastal strip and came to sea fishing later. Except for the Digo people in the south, most Mijikenda adhere to traditional African beliefs or to Christianity.

The large majority of the Swahili and Bajun are Muslims. The Swahili are generally considered as the offspring of inter-marriage between African and Arab groups over a long period and they have dominated the coastal strip for centuries. The Bajun are considered either a part of the Swahili or as an ethnic group in their own right (see Elliot, 19251926; Prins, 1972; Middleton, 2000). The Bajun are regarded as the traditional fishermen per excellence on the Kenyan coast.

\section{Survey techniques}

The study was part of a larger research project on income diversification and the management of resources among coastal fishermen in Kenya. ${ }^{1}$ This project was made up of four surveys (referred to as companion surveys) and four support studies. The present study was one of the support studies undertaken in the course of 2000 in the two areas described above. In Uyombo, 23 informants - 13 fishermen and 10 household members - were interviewed on a number of occasions using different techniques. In Takaungu, 21 informants - 11 fishermen and 10 household members - were interviewed. The fishermen were contacted at the respective landing sites and accompanied to their homesteads in order to interview other household member(s), such as wives.

Data gathering techniques included semistructured, unstructured and informal interviews, life and career histories, participant observation, time allocation studies and discussion groups (see Versleijen (2001) for full details). Households and informants were contacted more than once to verify information and to elaborate on information given earlier. On the first visit, semi-structured interviews were collected and during later visits, unstructured and informal interviews as well as life and career histories were compiled. Most of the fishermen $(65 \%)$ were followed for a whole day using a technique known as participant observation. (The other fishermen refused to participate because they did not want an extra person in their boat and, moreover, a woman). Time allocation studies were undertaken by visiting all informants every hour for one day. Discussion groups took on an organized form in Uyombo and were more informally arranged in Takaungu.

Follow-up interviews of an informal nature were held in 2001 and 2003 with several fishermen and others in Takaungu and some fishermen from Uyombo. Most had been part of the earlier samples and wanted to add something or update their situation, while others became involved in the conversations and added their views. Discussions focused on questions such as current household income, the possibility of income diversification and views concerning marine conservation and the Marine National Park.

\section{RESULTS}

\section{Access and fishermen numbers}

Most fishermen were aware of the degradation of marine resources and mentioned declining fish catches in this respect. The fishermen themselves stated different reasons for declining catches but the primary cause, according to them, was the increased number of fishermen. Other reasons mentioned were the gazetting of the Marine National Park, unpredictable weather patterns (notably the heavy El Niňo rains in 1997/98), and the annual visits of migrating fishers from Pemba Island in Tanzania. The increased number of fishermen put more pressure on already limited marine resources, particularly in the case of Uyombo. If this was indeed a major cause of the decline in incomes, it is not clear why people would start fishing or why new

\footnotetext{
${ }^{1}$ This was a joint project of Moi University (Kenya), Ben Gurion University (Israel) and the African Studies Centre (Leiden) between 1999 and 2001. It was funded by the Netherlands Israel Research Project, contract NIRP-97-145-7, and is reported in Hoorweg et al. $(2003,2008 a)$.
} 
entrants were not prevented from starting fishing. The answers to these questions are reflected in the quotes below.

If there were other jobs I would do something else, but you know it is hard to find a job these days, even the tourist hotels are not offering many jobs anymore. (Mijikenda fisherman, Takaungu)

My family is a family of farmers. When I was born, there were no fishermen in the family. We had been farming for a long time, my grandfather and his father and so on. Since they could live very well off farming, why would they do something else which they did not know how to do? But when I was young, the harvests were not that good anymore and it was a problem for me to live off farming alone when I wanted to start a family. So I started fishing. Another fisherman took me out and taught me how to do it. That is all. Everyone can start fishing; nobody can stop anyone from fishing. And some of my sons started to help me fish and they will become fishermen as well! (Mijikenda fisherman, Uyombo)

The fishermen stated that they did not own the sea, everybody was welcome and as long as they did not use the marine resources in a harmful way, no action would be taken.

We do not own the sea; it is the KWS that thinks you can own the sea! The sea belongs to everybody; so one fisherman can never deny another fisherman the right to go fishing unless that fisherman is fishing in a way that is not accepted by the other fishermen. You know like the Wapemba, we chased them because they were ruining everything! (Retired Bajun fisherman, Uyombo $)^{2}$

This quote shows that the fishermen were aware that marine resources need to be protected from outsiders and the fishing communities did have some form of access control albeit with limited means of enforcement. The fishermen of Takaungu were organized in a fishermen's committee.
New fishermen had to apply to the committee's chairman to obtain permission to fish. He would then introduce them to the other fishermen and the chief. The only reason to deny someone permission to fish in Takaungu was the gear used or a particular fisherman's reputation. Even Takaungu residents who wanted to fish had to get permission from the chairman. However the chairman, who had served in this position for the past twelve years, ${ }^{3}$ admitted that not everyone had sought his approval but as long as they did not use harmful gear and did not cause trouble, this was not an issue.

We don't have ways to enforce things, except that when we are all together we are strong. I mean that when we all agree that something should not be done, we can chase away the people who do it. In the past, all the fishermen came to me to ask permission to fish here but nowadays that is not the case. Not that that is a problem, it is okay as long as they don't fish with bad gear, like the nets with very small mesh sizes. (Chairman of the fishermen's committee in Takaungu)

A village committee existed in Uyombo, of which most of the fishermen living outside Uyombo were members as well. The role of this committee was mainly to facilitate internal communication and represent the group with external actors. The committee had meetings with officials concerning the Marine National Park and information could be passed on to the fishermen through the committee. If there were complaints, the committee would deal with them. Also, new fishermen had to seek the committee's approval and permission. The committee in Uyombo worked quite efficiently, an example being the expulsion of the Pemba fishermen and the discussions concerning the Marine National Park that were going on during the research period.

Many of the fishermen who had started fishing recently were Mijikenda and this group formed the majority of the new generation of fishermen. Although this new generation was partly blamed for the declining catches, they were accepted as long

\footnotetext{
${ }^{2} \mathrm{~A}$ similar example is the refusal of Tanzanian fishermen at Vanga, as described by Hinrichsen (1998).

${ }^{3} \mathrm{He}$ was still there in 2006 during our follow-up visit to Takaungu.
} 
as they did not use harmful fishing gear. The old generation of fishermen were not hostile towards the new generation and considered it logical that people would try to make an income from fishing and expand their other income-generating activities. Farmers did not have problems either with fishermen who were buying or renting land to start farming. Assistance was given in both directions: the old generation showed the new generation how to fish, and fishermen starting to farm could ask for advice.

\section{The fishermen's identity}

Fishermen were from families with different occupational backgrounds. There were fishermen with a family history of fishing dating back several generations and there were also fishermen who had a family background in other sectors, most frequently in farming. A companion survey showed that two-thirds of the fisher households had farming land but it was mainly the Mijikenda who were involved in farming and not the Bajun (Hoorweg et al. 2008a). The percentage of fishermen with only one previous generation involved in fishing or no background in fishing at all - the new generation of fishermen - was much higher in the Uyombo sample than in Takaungu ( $77 \%$ compared to $36 \%$ respectively).

There are several reasons for the arrival of this new generation of fishermen. In most cases, the plot of land they had inherited from their father was not sufficient to feed a whole family and new land was hard to obtain due to increasing pressure on land, which had resulted in rising prices and declining availability. It was increasingly difficult to find money to cover the education of children and they often dropped out of school and turned to fishing. Reasons for starting fishing in Uyombo and Takaungu seem to be similar: there were not enough jobs available.

My father and his three brothers were drivers and they all started living in Takaungu. Later my father joined the land council and reallocated land. In this way he made a lot of money but people started to dislike him. Now he has no job, he is an old man. I'm the eldest son and I was the first in the family to start fishing. I want to become a driver like my father was but I don't have the necessary certificate. I'm also growing tomatoes on a piece of land. When my sons and little brothers are older, I'll teach them how to fish. This way they will make a higher income. (Mijikenda fisherman, Takaungu)

The absence of alternative employment opportunities was particularly evident in Uyombo where fishing is often the only option people have besides farming. In Takaungu there were more employment opportunities because of access to urban areas, the larger size of the town and there was one local activity that one could always be pursued, namely stone block cutting. In nearby Timboni, stone-block cutting was carried out on an industrial scale (using machines) and on a much smaller scale as a form of self-employment, using hand tools with the blocks sold to middlemen. The latter activity was not popular because it is hard physical work and it takes time to acquire the skills necessary to make it a profitable activity. Conversely, many people stated that a man who was good at cutting blocks could make a reasonable income out of it, but the required tools still had to be bought. Since block cutting was not popular, there was nearly always a pit available.

It is relatively easy to enter the fishing profession at little cost, for example as crew member or as speargun fisher, and it could even be done seasonally during periods when other activities did not demand much labour or did not provide sufficient income. Most fishermen started fishing at a young age (Table 2), with onthe-job training while assisting their father, uncle or friends. They often became experienced in the use of a certain type of gear and then kept using it. The new generation usually learned from the older fishermen.

Table 2. Age at which fishermen started fishing (\%)

\begin{tabular}{ccc}
\hline Age & $\begin{array}{c}\text { Uyombo } \\
(\mathbf{N = 1 3})\end{array}$ & $\begin{array}{c}\text { Takaungu } \\
(\mathbf{N}=11)\end{array}$ \\
\hline $10-15$ & 46 & 27 \\
$15-20$ & 31 & 27 \\
$20-25$ & 15 & 27 \\
$25-30$ & 8 & 0 \\
$30-35$ & 0 & 9 \\
$35-40$ & 0 & 9 \\
\hline
\end{tabular}


Everybody can start fishing whenever he wants and in the way he wants. It is not like you have to look for it for a long time and to go through a lot of trouble. (Mijikenda fisherman, Takaungu)

When I was at school I often went swimming at Bandarini, you see people fishing. It is an easy way to make your living, so I started fishing. (Mijikenda fisherman, Uyombo)

Most fishermen considered themselves firstly as fishermen and saw their other activities as supplementary. This also applied to the new generation of fishermen. Fishing gives status because it is considered more of a real job than farming, which is often of a subsistence nature. Some farmers who had started to fish stated that they considered themselves fishermen more than farmers because 'with fishing you really have to go out, you leave your own place and you go to another place'. The direct income one can earn from fishing also influences the fact that people considered themselves fishermen rather than farmers.

As a fisherman I go out in the morning and bring back money in the evening or at the end of the week. It is like being employed, you work and you get paid. With farming you often have to wait till you harvest or you have to start making products you can sell immediately, like mnazi (palm wine). (Mijikenda fisherman, Uyombo)

I only construct houses during the kusi season and in addition I farm throughout the year if the rains are good enough. But I am a fisherman, that is what I make my living from. The farming, which my wife and I are doing, is small scale, just to get some food. We don't get money out of that. (Mijikenda fisherman, Takaungu)

Another reason for the higher status of fishing is that fishing activities are a male prerogative. Fishing is generally considered not to be suitable for a woman (although there were incidental exceptions elsewhere along the coast). Women are however involved in the marketing and processing of the fish caught. As one of the (Muslim) fishermen said:

God did not make a man and a woman to go out fishing together, the man should do the fishing and the woman should stay at or near the house. (Bajun fisherman,

Takaungu)

Some fishermen claimed women were not physically strong enough to fish. One of the speargun fishermen phrased it this way:

I cannot imagine my wife going out, swimming up to the good fishing places and then chasing the fish. (Mijikenda fisherman, Uyombo)

While the new generation of fishermen did diversify their income by starting to fish and gained a new identity in the process, the old generation of fishermen who sometimes (or, in the case of Uyombo, often) became involved in nonfishing activities were not tempted to change their identity. They were fishermen first and foremost. An important aspect to note is that among the new generation of fishermen, it was the head or grown-up children in the household who diversified their household's income by starting to fish. On the other hand, among the old generation, the fisherman himself might seek another job (activity diversification) but it could also be the wife or the grown-up children who would start other activities like agricultural wage labour or self-employment (earner diversification). It should also be noted that if a farmer starts fishing, he withdraws part of his labour from the farm. His wife then often has to spend more time farming and is limited in possibilities to engage in other income-generating activities. (See also Hoorweg et al., 2008b).

\section{Fishing gear}

The choice of gear was influenced by the fishermen's knowledge and experience as well as economic and environmental considerations. Fishermen were flexible in their use of gear, although they usually had strong preferences based on experience and their expected catches.

I use a speargun because it gives me a good catch. I have never fished with anything else, this is what I am used to. If I started using some other sort of gear I would have to learn how to use and make it. (Mijikenda fisherman, Takaungu)

Traditional gear included traps, fences and poison. The portable fish traps (malema) were fairly 
light and were used on the reef. Fixed fences (uzio), usually made of thin branches and brushwood bound together, were set perpendicular to and up onto the shore. Traditional fish poison (mkanga or mchupa) was sometimes used, killing other marine organisms as well as birds that eat the dead fish. Modern equipment included nets and lines in almost equal proportion. The use of a gill-net (mpweke) sometimes involved the fishermen trampling on the reef crest and these nets can snag on the reef and break off corals. Beach seines (juya) had very small mesh sizes and young and immature fish became entangled in them as by-catch. The net was dragged along the seabed, churning up the sea bottom and damaging underwater vegetation. Baited hooks and lines (mishipi) usually did not interfere with the marine environment. Spear fishermen used long metallic rods (mkonjo) to break the coral where fish had taken refuge and sometimes spears damaged the coral if fishermen missed their targets. Explosives (baruti) kill fish and other marine life indiscriminately and also damage the habitat, reducing the reef to a layer of small pieces of coral and loose rubble.

In one of the companion surveys, it was found that about $15 \%$ of fishermen freely admitted to using harmful equipment: $9 \%$ reported using spearguns, $5 \%$ mentioned beach seines and 3\% used a net mesh size of less than 1 inch (Hoorweg et al., 2008a). ${ }^{4}$ These types of gear were used more often by Mijikenda fishermen than Bajun fishermen (25.0\% and 2.4\% respectively). Many new-generation fishermen stated that they used the gear they either had learned to fish with or that was easiest to assemble and not too expensive, but these were often the more harmful types. Many young fishermen, often school drop-outs, used spearguns because they were easy to make and use.

\section{Fishing grounds and conservation}

Fishermen did not limit themselves to one fishing ground or even one landing site. Many fishermen on the Kenya coast were (seasonal) migrants and operated from different landing sites at different times of the year. Once a fisherman had gained sufficient experience and if he was still young, he was free to become a migrant fisherman. When older and having started his own family, he would give up moving along the coast but could still turn to seasonal migration, usually during the high season (the kaskazi or northeast monsoon). The fishermen claimed that fishing elsewhere was not worth the effort in the low season (the kusi or southeast monsoon) as catches at other landing sites in this season were only slightly different.

The new generation of fishermen, due to their involvement in other income-generating activities, were often non-migrant fishermen or seasonal migrants. Exceptions did occur if, for example, someone's son started fishing because he would have more freedom and fewer responsibilities at home. Most of the fishermen in Takaungu reported that they used to fish at other landing sites when they were young and had, in effect, been migrant fishermen.

Certain fishing grounds were avoided at certain times of the year. In this respect, there was a clear difference between the high and low seasons. During the low season when the sea can be rough, fishermen avoided the deep waters and outer-reef areas. In the high season, they fished less often in the lagoon, giving these grounds some respite, but much depended on the vessels involved.

Restricting access to particular fishing grounds in the form of a seasonal or all-year ban is an important conservation measure. In the past, there were traditional restrictions, such as the sadaka ceremony but they have largely disappeared. Most of the fishermen from Takaungu were aware that there used to be something called sadaka, although descriptions of the purpose of the ceremony and the precise ritual differed considerably. ${ }^{5}$

We used to bring offerings to the sea and then we would not fish in that area for at least a week. Some areas you would not go to at all. (Bajun fisherman)

Some Mavumba (pounded fish which has a very strong smell, the smell is the important thing about it, it can be rotten as well) are

\footnotetext{
${ }^{4}$ None of the fishermen admitted to using poison or explosives but reliable sources confirmed that poison was used in the northern part of Malindi District and that explosives were occasionally used between Mayungu and Watamu.

${ }^{5}$ For descriptions of the sadaka, see Glaesel (1997, 2000), McClanahan et al. (1997) and Versleijen (2001).
} 
taken to the sea and words are said and celebrations are held. This can be anywhere in the sea, the place is chosen by all the fishermen together. (Mijikenda fisherman) There is a sadaka when blood should be given to the sea. A goat is slaughtered and prepared and eaten. Some is given to the sea. Older fishermen say some words to the gods of the sea to ask them for a bigger catch. After the sadaka there should not be any fishing at the spot of the sadaka for a week. This sadaka is not done here anymore, there are too many fishermen now and they do not cooperate anymore. The older fishermen who always arranged this died years ago. I think the last sadaka like this must have been 10 years ago. (Swahili fisherman)

In November 2000, it was decided to hold another sadaka. However, only nine fishermen participated in the ceremony, all of whom were over the age of 40 . The ceremony consisted of eating on the beach, giving some food to the sea and not fishing at that spot on the day of the ceremony, but this only involved the people who had participated in the ceremony. The new-generation fishermen were conspicuous by their absence.

In fact, the latter were often blamed for the demise of the sadaka. They supposedly lacked the emotional connection with the marine resources found among the Bajun people, for example. The Mijikenda fishermen in this study did not think that performing a sadaka would improve their catches. They regarded the sadaka as a Muslim ceremony rather than a ceremony for fishermen. However, it is questionable whether this was indeed the main reason for the end of the sadaka. Many fishermen blamed the hard economic times that had forced them to abandon the practice.

I have to feed my family. If I don't fish for

some days or so, who will feed my family?

It is already difficult enough to get money

to send the children to school. (Swahili

fisherman)

The main restriction enforced nowadays is imposed by the Marine Protected Areas (MPAs) consisting of Marine National Parks and Marine National Reserves. Among the new generation of fishermen, knowledge of rules and regulations concerning MPAs was mainly based on case knowledge, why people were arrested and the information given by the KWS on these occasions. The list of regulations was long, however, and many of the existing rules were not commonly known to the new generation of fishermen, or they were known only in part or incorrectly. Since knowledge about the rules and regulations concerning the Marine National Park and Reserve was mainly based on cumulative experience, the old generation of fishermen, having known the Marine Park from the start, could draw on a larger pool of knowledge, either directly or through family relations. The new generation of fishermen were helpless when arrested by KWS rangers for committing an offence.

Table 3 summarizes the views of fishermen on marine conservation and the role of marine protected areas. Fishermen mentioned some benefits from the park, like increased security, but considered them all to be marginal because the fishermen did not seem to benefit in terms of

Table 3 Views of fishermen on resource conservation by landing site (\%)

\begin{tabular}{lcc}
\hline & $\begin{array}{c}\text { Uyombo } \\
(\mathbf{N = 1 3 )}\end{array}$ & $\begin{array}{c}\text { Takaungu } \\
(\mathbf{N = 1 1 )}\end{array}$ \\
\hline Need of Sadaka and related rules and regulations & 0 & 18 \\
Need of marine conservation & & 91 \\
MPA as suitable way of marine conservation & 100 & 0 \\
MPA as suitable way of marine conservation if managed & 0 & 9 \\
differently than at present $^{2}$ & 31 & 9 \\
\hline
\end{tabular}

\footnotetext{
${ }^{1}$ Question asked regardless of the kind of marine conservation. Most fishermen who answered positively to this question referred to declining fish catches.

${ }^{2}$ Most fishermen from Uyombo who answered positively to this question referred to "the former warden of the Park who helped us and let us even fish in some places in the Park when our catches were low, he was thinking of us as well, not only of the wazungu."
} 
employment opportunities from the presence of the KWS or the Park. The promised spillover of fish from the Marine National Park, according to them, was not in evidence either.

There is no spillover benefit from the Marine

National Park. It is a lie. Even before the Marine National Park was set up, there were more fish than nowadays. Today fish are rare and the fish that are there, they escape to the park. (Bajun fisherman)

Fishermen in Uyombo expressed considerable resentment towards the Park and the KWS wardens (see also Versleijen \& Hoorweg 2006). The new generation of fishermen in particular displayed a hostile attitude towards the Marine National Park, more so than the old generation of fishermen. Whereas the latter expressed a dislike of the Park, the new generation showed clear signs of aggression towards it. During one of the village committee meetings in Uyombo in 2000, many of the fishermen from the old generation did in fact find solutions to various problems through discussions with the KWS, whereas the new generation of fishermen favoured more dramatic action like 'fishing the park empty' or 'chasing all the white people'. It was the old generation of fishermen who mentioned certain benefits from the Park, while the new generation mainly saw it as an obstruction to realizing a livelihood.

\section{DISCUSSION}

Poverty has often been associated with the overexploitation of natural resources. Ellis (2000) notes that environmental degradation worsens the degree of poverty of marginal groups and in turn leads to more intensive exploitation of accessible resources. The implicit assumption is that an improvement in income levels will lessen the pressure on resources and halt further damage to the natural environment. Poverty itself has to be addressed because the poor have to be given access to other sources of livelihood. However, the expectation that higher incomes would halt environmental destruction has not generally been confirmed (Ellis, 2000). This was reinforced in one of the companion surveys where it was found that fishermen with more than one income-generating activity did not put any less pressure on fishing resources (Hoorweg et al., 2006, 2008a). In fact, there were strong indications that they put more pressure on them, fishing inshore more frequently and using damaging equipment more often.

The topic of income diversification in relation to fishing is usually defined in terms of fishermen seeking other income-generating activities. However, there is also a reverse process whereby people with economic activities on land turn to fishing on a part-time basis. This new generation of fishermen has little or no prior knowledge of fishing and the nature of marine resources. This paper has tried to address the question of what this means for the state of fishery resources. Four subject areas were reviewed: access and fishermen numbers; the fishermen's identity; the fishing equipment they use and their choice of fishing grounds.

Income diversification is a widespread survival strategy in rural households to sustain one's livelihood but also to spread risks, for example, to meet temporary unemployment, seasonal shortages and failed harvests (Ellis, 2000). Due to a shortage of land and a lack of employment opportunities, more people are turning to fishing. Although fishermen cannot control the fish, in principle they can determine who is allowed to fish and in what way (Acheson, 1981; Oström, 1999; Charles, 2001). However, fishermen did not see increasing numbers of fishermen and declining fish catches as a reason to deny entry to others. Due to a lack of effective restrictions on access, new fishermen were easily accepted. With the Beach Management Units (BMUs) an attempt is being made to control access and entry. Each BMU has jurisdiction over a landing site and the Fisheries Department designates a comanagement area where the two share management responsibilities (Olouch et al., 2006). In addition, fishermen will have to seek permission from the local BMU to fish at another landing site.

Since the 1960s, there has been an influx of Mijikenda fishermen, an ethnic group that does not have a history of fishing and has little traditional knowledge about how to manage marine resources and provide apprenticeships for young fishermen (Glaesel, 1997). They mainly form the new generation of fishermen. Data on how many fishermen with a non-fishing background have started fishing do not exist, nor do data on the increase in the number of fishermen as a result of 
the natural population growth, but it was generally agreed that there had been a sizeable entry of new fishermen over the past two decades. It is easy to blame this new generation for the degradation of local marine resources. However by and large, the new-generation fishermen had started fishing when their previous source of income was no longer sufficient to sustain their household. The ultimate cause, therefore, has to be sought in the economic situation and in the hardships experienced by many households along the coastal strip. It is unlikely that they would have turned to fishing if there had been other more attractive employment opportunities.

Fishing was considered more of a real job than, for example, farming. Even the new generation of fishermen considered themselves fishermen first, even if another income-generating activity made a larger financial contribution to the household. Certain aspects of fishing are more highly valued than other income-generating activities. First and foremost was the fact that in order to go fishing one has to leave the homestead, even the village, and set out to sea. This reinforced the notion of 'going to work' where one is in the company of fellow fishermen. Secondly, fishing was a male-dominated activity and one that belonged to an occupational group. Thirdly, in most cases a fisherman brought home cash on the same day. Therefore the new generation had not only diversified their income but also joined a group with another identity.

Equipment differs greatly in its effect on the environment, some is destructive, others not. There are roughly three types of harmful effects: 1) damage to the marine environment; 2) the capture of non-targeted species; and 3) the capture of immature targeted species. Not only the type of gear but also the area where it is used and the way it is used determine whether it is destructive or not. Traditional gear was generally considered less damaging than modern equipment but the former appeared to be declining in popularity.

The new generation of fishermen used harmful gear more often than the old generation of fishermen. Glaesel (1997) also claimed that an influx of people from non-fishing communities like the Mijikenda - was to blame for the increased use of unsustainable fishing methods and they were causing extra degradation of marine resources. Furthermore, due to declining fish stocks and a loss of fishing knowledge, fishermen were increasingly turning to less expensive and more harmful methods of fishing.

If a fisherman started fishing in combination with another income-generating activity, he was more likely to fish inshore and with the gear that brought him the highest catch. This equipment was often of the more destructive type. Moreover, those fishermen often lacked the time, and especially the skills, to make traditional gear, like the malema. This forced them to use modern gear which is generally not biodegradable. Destructive gear was mentioned as one of the few reasons for refusing a person permission to fish, although in practice this rarely happened, with the notable exception of the incident in Uyombo, mentioned earlier, where migratory Pemba fishermen were chased from the landing site because they were using destructive gear.

Traditional restrictions on access to fishing grounds, such as the sadaka, had largely been abandoned. Although there was still an interest among the old generation of fishermen in the ceremony, the new generation of fishermen did not see a use for it and regarded it as a Muslim ceremony. Still, the indications are that general economic conditions are playing a role in the demise of the ritual. Other reasons that were mentioned were the arrival of many young fishermen and a lack of environmental knowledge (Tunje and Hoorweg, 2003).

MPAs impose the main restrictions that are enforced nowadays. Knowledge about existing rules and regulations pertaining to the Park was poor, especially among the new generation of fishermen, who were helpless whether arrested for real offences or because of false accusations. Perhaps this was one of the reasons why the new generation of fishermen expressed a more hostile attitude towards the Park than the old generation. They perceived the intervention of the KWS mainly as a hindrance, unreasonably placed in their way and felt that the Park offered no clear benefits, and only disadvantages. The main disadvantage was that some parts of the (best) traditional fishing grounds were off-limits. A positive effect that can be expected from fishing restrictions is an increase in fish biomass (Cinner et al., 2005), and spillover of exploitable fish into the reserves and surrounding 
areas to the benefit of local fishermen (McClanahan and Mangi, 2000). However, this effect can be nullified by a greater concentration of fishermen in a smaller area (Ochiewo, 2004).

Half the fishermen interviewed in one of the companion surveys expressed an interest in opting for alternative employment, although it was considered unlikely that they would abandon fishing completely even if they found employment (Hoorweg et al. 2006). Creating local employment opportunities as a means of relieving pressure on fishing resources is a scenario with pitfalls. It is unlikely that employment opportunities will tempt the current fishermen away from fishing and it is impossible to predict whether new opportunities will prevent potential fishermen from starting fishing. Much depends on the kind of employment opportunities that emerge and whether they are formal jobs in industry or services, or whether they are merely an extension of existing employment opportunities in the agricultural or informal sector.

Incomes from fishing accounted for a large proportion of household incomes, even when there were additional income sources (Hoorweg et al. 2008a). Fishing will always remain attractive because it has few restrictions, can be taken up at any time and offers instant income, which is particularly important for cash-strapped rural households. To entice potential new fishermen away, any other source of employment would have to be full-time, financially rewarding and offer an identity to match the status provided by fishing. It is also quite possible that new employment opportunities would attract workers from elsewhere, perhaps with better job qualifications, who, in turn, will discover the possibilities that fishing offers as a source of extra income.

\section{REFERENCES}

Acheson, J.M. (1981). Anthropology of Fishing. Annual Review of Anthropology. 10: 275-316.

Aloo, P. (2000). Marine Resources. In Hoorweg, J., Foeken, D. \& Obudho, R.A. (eds.), Kenya Coast Handbook: Culture, Resources and Development in the East African Littoral. Lit Verlag, Hamburg. Pp. 43-60.
Charles, A. (2001). Sustainable Fishery Systems. Fish and Aquatic Resources Series 5. Blackwell Science, Oxford. 370pp.

Cinner, J., Marnane, M. J., McClanahan, T. R. \& Almany, G. R. (2005). Periodic Closures as Adaptive Coral Reef Management in the IndoPacific. Ecology and Society 11(1): 31.

Cinner, J. \& McClanahan, T.R. (2006). A Baseline Socioeconomic Assessment of Fishing Communities along the North Coast of Kenya. Mombasa: Wildlife Conservation Society's Coral Reef Conservation Project. 28pp.

Elliot, J.A.G. (1925-26). A Visit to the Bajun Islands. Journal of the African Society. 25: 10-20, 147-163, 245-263, 338- 358.

Ellis, F. (2000). Rural Livelihoods and Diversity in Developing Countries. Oxford University Press, Oxford. 273pp

Glaesel, H. (1997). Fishers, Parks and Power: The Socio-environmental Dimensions of Marine Resource Decline and Protection on the Kenya Coast. (Ph.D. Thesis). University of Wisconsin, Madison. 331pp

Glaesel, H. (2000). Community-level Marine Resource Management and the Spirit Realm in Coastal Kenya. Women in Natural Resources. 21(4): 35-42.

Government of Kenya (1964). Report on Kenya Fisheries. 1963. Government of Kenya, Nairobi.

Government of Kenya (1991). The Fisheries Act, Laws of Kenya, Chapter 378, Revised Edition. Government of Kenya, Nairobi.

Hinrichsen, D. (1998). Coastal Waters of the World: Trends, Threats and Strategies. Island Press, Washington. 275pp

Hoorweg, J., Degen, A. \& Wangila, B. (2003). Income Diversification and Resource Conservation among Artisanal Fishers at the Central Kenyan Coast. (NIRP End Report). African Studies Centre, Leiden. 154pp

Hoorweg, J., Versleijen, N., Wangila, B. \& Degen, A. (2006). Income Diversification and Fishing Practices among Artisanal Fishers. Paper presented at Coastal Ecology Conference IV, Mombasa, 2930 May 2006.

Hoorweg, J., Wangila, B. \& Degen, A. (2008a). Artisanal Fishers on the Kenya Coast: Household Livelihoods and Marine Resource Management. Leiden. 146pp (in press)

Hoorweg, J., Wangila, B. \& Degen, A. (2008b). Livelihoods and Income Diversification among Artisanal Fishers on the Kenyan Coast. African Dynamics (in press). 
Koffsky, P. (1977). History of Takaungu East Africa 1830-1896. (Ph.D. Thesis) University of Wisconsin, Madison. 221pp

McClanahan, T.R. (1996). Oceanic Ecosystems and Pelagic Fisheries. In McClanahan, T.R. \& Young, T.P. (eds.), East African Ecosystems and their Conservation. Oxford University Press, Oxford. Pp 39-66.

McClanahan, T.R., Glaesel, H., Rubens, J. \& Kiambo, R.W. (1997). The Effects of Traditional Fisheries Management on Fisheries Yields and the Coral-Reef Ecosystems of Southern Kenya. Environmental Conservation. 24(2): 105-120.

McClanahan, T.R. \& Mangi, S. (2000). Spillover of Exploitable Fishes from a Marine Park and its Effect on the Adjacent Fishery. Ecological Applications. 10(6): 1792-1805.

McClanahan, T.R., Mwaguni, S. \& Muthiga, N.A. (2005). Management of the Kenya Coast. Ocean \& Coastal Management 48: $901-931$

McClanahan, T.R. \& Obura, D. (1995). Status of Kenyan coral reefs. Coastal Management, 23: 57-76.

McClanahan, T.R. \& Obura D. (1996). Coral Reefs and Nearshore Fisheries. In McClanahan, T.R. \& Young, T.P. (eds.), East African Ecosystems and their Conservation. Oxford University Press, Oxford. Pp. 67-99.

Middleton, J. (2000). The Peoples. In Hoorweg, J., Foeken, D. \& Obudho, R.A. (eds.), Kenya Coast Handbook: Culture, Resources and Development in the East African Littoral. Lit Verlag, Hamburg. Pp. 101-114.

Obura, D. (2001). Kenya. Marine Pollution Bulletin, 42(12): 1264-1278.

Ochiewo, J. (2004). Changing Fishery Practices and their Socioeconomic Implications in South Coast Kenya. Ocean \& Coastal Management, 47: 389-408.

Oluoch, S.J., Obura, D. \& Hussein, A. (2006). The Capacity of Fisher Folk to Implement Beach Management Units in Diani-Chale, Southern
Kenya. Paper presented at Coastal Ecology Conference IV, Mombasa, 29-30 May 2006.

Oström, E. (1999). Coping with Tragedies of the Commons. Annual Review of Political Science, 2: 493-535.

Prins, A.H.J. (1972). The Shungwaya Problem, Traditional History and Cultural Likeness in Bantu North East Africa. Anthropos: International Review of Ethnology and Linguistics, pp. 9-35.

Tunje, J.G. \& Hoorweg, J. (2003). Awareness of Resource Degradation among Artisanal Fishermen in Kilifi and Lamu. In Hoorweg J. \& Muthiga N. (eds.), Recent Advances in Coastal Ecology: Studies from Kenya. African Studies Centre, Leiden. Pp. 185-200.

UNEP (1998). Eastern Africa Atlas of Coastal Resources: Kenya. UNEP, Nairobi. 119pp.

Versleijen, N. (2001). An Empty Sufuria: The Effects of a Marine National Park on the Livelihood Strategies and Income Diversification of Fishermen Household at the Kenya Coast. (M.A. Thesis). Wageningen University and Research Centre. $141 \mathrm{pp}$

Versleijen, N. \& Hoorweg, J. (2006). Marine Conservation: The Voice of the Fishers. Paper presented at Coastal Ecology Conference IV, Mombasa, 29-30 May 2006.

Waaijenberg, H. (1993). Land and Labour in Mijikenda Agriculture, Kenya, 1850-1985. Research Reports African Studies Centre: 53. Africa Studies Centre, Leiden. $51 \mathrm{pp}$

Waaijenberg, H. (1994). Mijikenda Agriculture in Coast Province of Kenya. (Ph.D. Thesis). Wageningen Agricultural University, Wageningen (NL). 307pp

Waaijenberg, H. (2000). Agriculture. In Hoorweg, J., Foeken, D. \& Obudho, R.A. (eds.), Kenya Coast Handbook: Culture, Resources and Development in the East African Littoral. Lit Verlag, Hamburg. Pp. 175-196.

Wikipedia (2008). Takaungu. Accessed on 04.03.2008. 